J. Gen. Appl. Microbiol.

Vol. 7, Suppl. 1, 1961

\title{
NEGATIVE FEED-BACK CONTROL CAUSED BY THREONINE AND METHIONINE IN L-HOMUSERINE FERMENTATION
}

\author{
HIROTOSHI SAMEJIMA, TAKASHI NARA, CHUZO FUJITA \\ and SHUKUO KINOSHITA \\ Tokyo Research Laboratory, Kyowa Fermentation Industry Co., Ltd. \\ Received for publication, Apriı 24, 1961
}

In 1948, TEST et al. (1) found a mutant strain of Neurospora crassa which requires both methionine and threonine for its growth, and also recognized that homoserine was able to replace the roles of those two amino acids. From this evidence, they suggested that homoserine might be a precursor for those two amino acids. In 1951, Fling and Horowitz(2) also reported that a methionine-less mutant of Neurospora crassa accumulated some amount of homoserine and threonine in its mycelia. Since then, it has become clear that homoserine is an important intermediate in the biosynthesis of essential amino acids such as threonine $(2,3)$, methionine $(2,3)$, and isoleucine $(3,4)$.

During the studies on fermentative production of various amino acids, the present authors found two threonine-less mutants of Micrococcus glutamicus (5) to have accumulated significant amounts of L-homoserine in their culture broths. This was reported in a preliminary paper $(6)$, and the details of the fermentation were also reported in previous papers $(7,8,9,10)$.

The present study confirmed the so-called " negative feed-back control" phenomena caused by threonine and methionine in the fermentative production of L-homoserine by Micrococcus glutamicus 534-Co 147 strain, which is a threonine-less mutant. In order to clarify the "negative feed-back control " phenomena, further experiments were carried out with both growing cultures and intact cell suspensions, and the possible sites of the "negative feed-back control" in the pathway of homoserine biosynthesis were discussed.

\section{EXPERIMENTAL METHODS}

\section{(I) Growing Culture Experiments}

(a) Strains used: Among many auxotrophs of Micrococcus glutamicus isolated by Nakayama et al (11) and many other species, two strains, i.e., M. glutamicus 534-185 and 534-Co147 (threonine-less mutants) were found to show a considerable accumulation of L-homoserine in their culture broths $(7)$.

In the present experiments, only $M$. glutamicus $534-$ Co147 strain was used.

(b) Culture media and methods: For seed culture, glucose-bouillon medium (glucose $1 \%$, peptone $1 \%$, meat extract $1 \%$ and sodium chloride 
$0.5 \% ; \mathrm{pH} 7.0$ ) was used. One loopful of the organism was transferred from a stock culture slant (glucose-bouillon medium with $2 \%$ agar-agar) to $10 \mathrm{ml}$ of seed medium in a sterilized test tube $(2.3 \mathrm{~cm}$ dia.), and the test tube was incubated on a reciprocal test-tube shaker for 24 hours at $30^{\circ}$.

One $\mathrm{ml}$ of seed culture thus obtained was transferred into $25 \mathrm{ml}$ of fermentation medium in a $250 \mathrm{ml}$-ERLENMYER's flask, and the flask was shaken at $28^{\circ}$ on a rotary shaker (220 r.p.m., $5 \mathrm{~cm}$ dia.).

Composition of fermentation media is given in each experiment described in the text.

Two parallel flasks were run for each analytical test in the growing culture experiments.

\section{(II) Intact Cell Experiments}

(a) Preparation of intact cell suspension: Ten $\mathrm{ml}$ of seed culture prepared as described in the preceding section was inoculated in $250 \mathrm{ml}$ of fermentation medium in a 2 L-ERLENMYeR's flask with two buffles, and the flask was shaken on a rotary shaker at $30^{\circ}$. After 40 hours' culture, the fermentation broth was harvested and centrifuged for 5 minutes at 400 r.p.m. $(30 \mathrm{~cm}$ dia.) in order to eliminate calcium carbonate from the broth. Then, the broth was again centrifuged for 20 minutes at 4,000 r.p.m. $(30 \mathrm{~cm} \mathrm{dia.})$ in order to collect bacterial cells. The cells were then washed twice with sterilized $0.9 \%$ sodium chloride solution by centrifugation. The washed cells were resuspended in sterilized $\mathrm{M} / 15$ potassium phosphate buffer ( $\mathrm{pH} 7.3$ ). The optical density of the snspension was measured at $660 \mathrm{~m} \mu$, and the cell density was calculated from a preliminarily prepared calibration curve and then adjusted to $100 \mathrm{mg}$ (dry cells)/ml with the same buffer.

(b) Preparation of reaction mixture and incubation: Reaction mixture contained $350 \mu M$ of potassium phosphate buffer ( $\mathrm{pH} 7.35$ ), $10 \mu M$ of magnesium sulfate, $100 \mu M$ of glucose, $200 \mu M$ of ammnium sulfate and $100 \mathrm{mg}$ (in dry weight) of intact cells in total volume of $5 \mathrm{ml}$. The reaction mixture was placed in a test tube $(1.5 \mathrm{~cm}$ dia.), and incubated on a reciprocal shaking device for 6 hours at $30^{\circ}$. After the incubation, the mixture was heated for several minutes in a boiling water bath in order stop the reaction, and then centrifuged. The clear supernatant thus obtained was used for homoserine and lysine assays.

As the blank, zero-time sample was treated in the same way, and the amounts of homoserine and lysine measured were corrected for those of the blank.

In order to get each analytical data, duplicate tube cultures run in parallel were assayed.

\section{(III) Analytical Methods}

(a) L-Homoserine assay: Quantitative determination of L-homoserine in culture broths and reaction mixtures was carried out by a turbidimetric bioassay method (7) with Escherichia coli 177-184(12) which was kindly 
furnished by Dr. B. D. Davis. L-Homoserine in culture broths and reaction mixtures was successfully determined by this method in the range between 10 to $50 \mu \mathrm{g} / \mathrm{ml}$ of L-homoserine.

(b) Determination of lysine: Lysine in culture broths and reaction mixtures was determined by a colorimetric method of NeLSON (13).

(c) Determination of glucose: Glucose in culture broths was determined by a colorimetric method of Somogyi (14).

(d) Measurement of bacterial growth: One $\mathrm{ml}$ of fermentation broth was placed in a conical centrifuge-tube and centrifuged for 10 minutes at 3,000 r.p.m. (20 cm dia.), and then the supernatant was discarded. One $\mathrm{ml}$ of $2 \mathrm{~N}$ hydrochloric acid was then added to the tube in order to dissolve calcium carbonate which contaminated in bacterial cells. Then the bacterial cell suspension in $2 N$ hydrochloric acid was immediately made up to $20 \mathrm{ml}$ with distilled water.

Optical density of the cell-suspension was measured by an electrophotometer with a $660 \mathrm{~m} \mu$ filter, and used as a measure for bacterial growth.

\section{RESULTS}

\section{(I) Growing Culture Experiments with Chemically Defined Media}

(a) Effect of biotin and L-threonine on the bacterial growth and the production of L-homoserine and L-lysine

M. glutamicus has originally been a biotin requiring organism(15). And also, M. glutamicus 534-Co147 strain, the organism used here, has been found to be a threonine requiring mutant. Therefore, it is interesting to examine the effect of biotin and threonine on both bacterial growth and L-homoserine productoin.

In Table 1, amounts of L-homoserine produced and bacterial growth under various concentrations of biotin and of L-threonine are shown. Also, amounts of L-lysine produced are presented in the same table, because Llysine has been found to be another main product in this fermentation $(6,7)$.

As shown in Table 1, increased amount of biotin caused better growth of bacteria, while L-homoserine and L-lysine production was rather stable if biotin concentration in the medium was $5 \mu \mathrm{g} / 1$ or more. However, if the concentration of biotin was less than $5 \mu \mathrm{g} / 1$, both bacterial growth and production of L-homoserine and L-lysine decreased to a great extent, and production of glutamic acid became predominant.

On the other hand, concentration of L-threonine caused more distinct change in the production of both amino acids. At 400 to $500 \mu \mathrm{g} / \mathrm{ml}$ of threonine concentration, usually $10 \mathrm{mg} / \mathrm{ml}$ or more of $\mathrm{L}$-homoserine was accumulated in the culture media. Maximum production of L-homoserine was attained in a medium containing $400 \mu \mathrm{g} / \mathrm{ml}$ of L-threonine and $5 \mu \mathrm{g} / \mathrm{l}$ of biotin. In this case, $13.5 \mathrm{mg} / \mathrm{l}$ of L-homoserine and $9.7 \mathrm{mg} / \mathrm{ml}$ of L-lysine were produced.

The results of Table 1 were diagramatically shown in Figure 1. 
Table 1. Effect of L-Threonine and Biotin on L-Homoserine and L-lysine Production in Growing Culture Experiments.

\begin{tabular}{|c|c|c|c|c|c|}
\hline \multicolumn{2}{|c|}{$\begin{array}{l}\text { Ingredient added } \\
\text { to the medium }\end{array}$} & \multirow{2}{*}{$\begin{array}{l}\text { Growth } \\
\text { (O.D.) }\end{array}$} & \multirow{2}{*}{$\mathrm{pH}$} & \multirow{2}{*}{$\begin{array}{c}\text { L-Homoserine } \\
\text { produced } \\
(\mathrm{mg} / \mathrm{ml})\end{array}$} & \multirow{2}{*}{$\begin{array}{l}\text { L-Lysine } \\
\text { produced } \\
(\mathrm{mg} / \mathrm{ml})\end{array}$} \\
\hline $\begin{array}{c}\text { L-Threonine } \\
\mu \mathrm{g} / \mathrm{ml}\end{array}$ & $\begin{array}{l}\text { Biotin } \\
\mu \mathrm{g} / l\end{array}$ & & & & \\
\hline 80 & $\begin{array}{r}0 \\
5 \\
10 \\
30\end{array}$ & $\begin{array}{l}0.025 \\
0.270 \\
0.271 \\
0.312\end{array}$ & $\begin{array}{l}5.6 \\
5.6 \\
6.1 \\
5.7\end{array}$ & $\begin{array}{l}0.30 \\
2.05 \\
2.22 \\
2.35\end{array}$ & $\begin{array}{l}0.60 \\
3.11 \\
4.08 \\
3.58\end{array}$ \\
\hline 200 & $\begin{array}{r}0 \\
5 \\
10 \\
30\end{array}$ & $\begin{array}{l}0.036 \\
0.470 \\
0.481 \\
0.573\end{array}$ & $\begin{array}{l}5.6 \\
6.2 \\
6.1 \\
5.5\end{array}$ & $\begin{array}{l}2.80 \\
3.05 \\
4.11 \\
4.39\end{array}$ & $\begin{array}{l}1.13 \\
5.66 \\
5.91 \\
7.68\end{array}$ \\
\hline 300 & $\begin{array}{r}0 \\
5 \\
10 \\
30\end{array}$ & $\begin{array}{l}0.041 \\
0.605 \\
0.655 \\
0.686\end{array}$ & $\begin{array}{l}5.7 \\
5.6 \\
5.6 \\
5.6\end{array}$ & $\begin{array}{l}0.75 \\
7.05 \\
8.15 \\
8.65\end{array}$ & $\begin{array}{r}1.38 \\
8.77 \\
12.40 \\
11.71\end{array}$ \\
\hline 400 & $\begin{array}{r}0 \\
5 \\
10 \\
30\end{array}$ & $\begin{array}{l}0.041 \\
0.600 \\
0.673 \\
0.681\end{array}$ & $\begin{array}{l}6.3 \\
5.6 \\
5.6 \\
5.6\end{array}$ & $\begin{array}{r}1.01 \\
13.50 \\
10.93 \\
12.63\end{array}$ & $\begin{array}{l}0.89 \\
9.70 \\
9.25 \\
8.80\end{array}$ \\
\hline 500 & $\begin{array}{r}0 \\
5 \\
10 \\
30\end{array}$ & $\begin{array}{l}0.058 \\
0.600 \\
0.710 \\
0.736\end{array}$ & $\begin{array}{l}5.6 \\
6.9 \\
6.5 \\
7.2\end{array}$ & $\begin{array}{r}1.52 \\
10.18 \\
11.75 \\
10.33\end{array}$ & $\begin{array}{l}1.15 \\
8.80 \\
7.81 \\
7.85\end{array}$ \\
\hline 600 & $\begin{array}{r}0 \\
5 \\
10 \\
30\end{array}$ & $\begin{array}{l}0.058 \\
0.690 \\
0.710 \\
0.735\end{array}$ & $\begin{array}{l}5.7 \\
8.6 \\
8.5 \\
8.7\end{array}$ & $\begin{array}{l}0.62 \\
8.23 \\
7.90 \\
6.85\end{array}$ & $\begin{array}{l}1.00 \\
6.35 \\
4.10 \\
4.01\end{array}$ \\
\hline
\end{tabular}

Basal medium: glucose $10 \%,\left(\mathrm{NH}_{4}\right)_{2} \mathrm{SO}_{4} 2 \%, \mathrm{CaCO}_{3} 2 \%, \mathrm{~K}_{2} \mathrm{HPO}_{4} 0.1 \%$, and $\mathrm{MgSO} 4$. $7 \mathrm{aq} 0.03 \%$

Fermentation was run at $28^{\circ}$ for 4 to 5 days.

From Figure 1, the response of homoserine and lysine production to the concentration of L-threonine can easily be seen. Productivity of lysine was predominant over productivity of homoserine if the concentration of L-threonine was less than $300 \mu \mathrm{g} / \mathrm{ml}$. On the contrary, homoserine production became predominant over lysine production if the concentration of $\mathrm{L}$-threonine was more than $300 \mu \mathrm{g} / \mathrm{ml}$.

Based on the evidence indicated above, the effect of biotin and L-threonine on the fermentative production of amino acids by $M$. glutamicus 534Co147 is schematically shown in Figure 2.

(b) Inhibitory effect of excess amount of L-threonine on the production of $\mathrm{L}$-homoserine and $\mathrm{L}$-lysine

As shown in Figure 1, highest production of homoserine was usually attained when L-threonine level in the medium was 400 to $500 \mu \mathrm{g} / \mathrm{ml}$. If the concentration of threonine was increased to more than $500 \mu \mathrm{g} / \mathrm{ml}$, a marked 
decrease of homoserine production was observed. A similar tendency was also observed in the case of lysine production in which more than $300 \mu \mathrm{g} / \mathrm{ml}$ of threonine always caused a severe depression of lysine production. From these results, it was supposed that a higher concentration of threonine in the culture medium gave some inhibitory effects on both homoserine and lysine production.

In order to get clearer results on the inhibitory effect of threonine, growing culture tests with feeding various amounts of threonine were carried out. The results are shown in Table 2.

As shown in Table 2, addition of $\mathrm{L}$ threonine did not cause any change in bacterial growth. However, both homoserine and lysine productions were decreased to a great extent. In this case, significant accumulation of lactic acid was observed paperchromatographically. Similar results were observed in glutamic acid fermentation(21) and valine fermentation (22). Glycine was also detected paperchromatogrophically in cul-
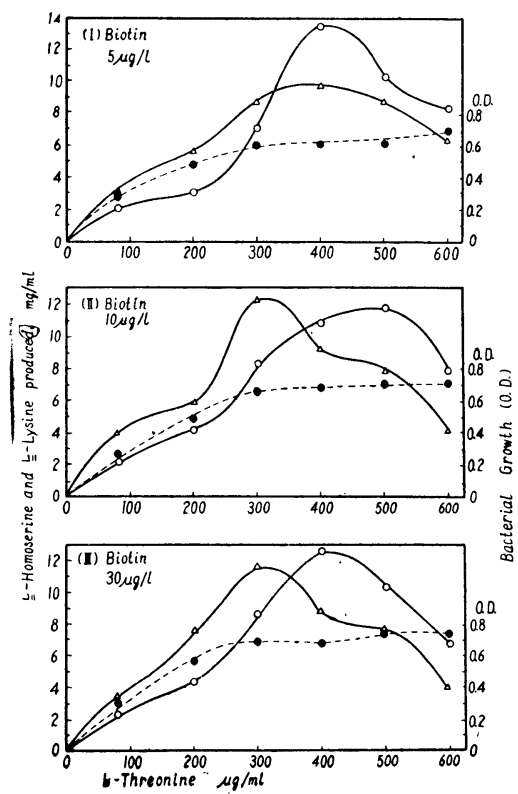

Fig. 1. Effect of L-Threonine and Biotin on Homoserine and Lysine Production.

$$
\begin{aligned}
& \triangle \longrightarrow \text { Homoserine } \\
& \triangle \longrightarrow \text { Lysine } \\
& --\triangle \text { Growth (O.D.) }
\end{aligned}
$$
ture broth when excess threonine was supplied. This suggested degradation of excess threonine to glycine by threonine aldolase $(23,24)$.
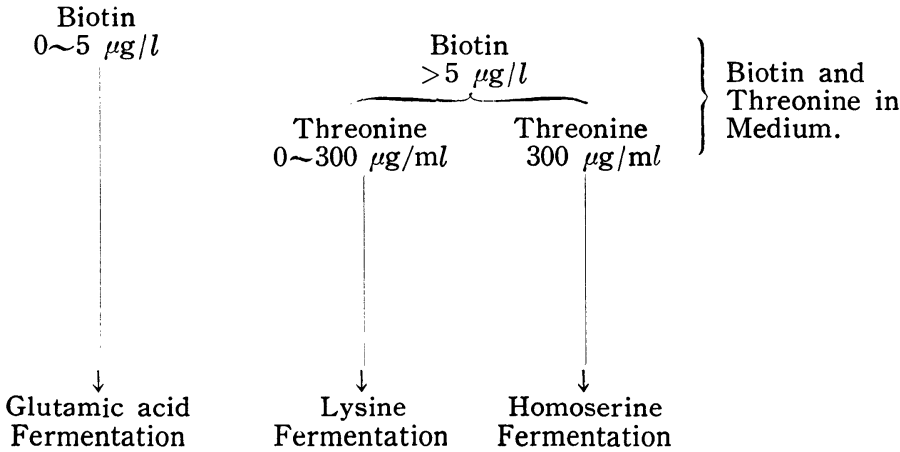

Fig. 2. Effect of Biotin and L-Threonine on Glutamic acid, Lysine, and Homoserine Production by Micrococcus glutamicus 534-Co147 Strain. 
Table 2. Inhibition of Homoserine and Lysine Production by Threonine.

\begin{tabular}{c|c|c|c|c|c|c}
\hline $\begin{array}{c}\text { L-Threonine } \\
\text { added }\end{array}$ & $\begin{array}{c}\text { Growth } \\
\text { (O.D.) }\end{array}$ & $\mathrm{pH}$ & $\begin{array}{c}\text { L-Homoserine } \\
\text { produced } \\
\text { (mg/ml) }\end{array}$ & $\begin{array}{c}\text { L-Lysine } \\
\text { produced } \\
(\mathrm{mg} / \mathrm{m} l)\end{array}$ & $\begin{array}{c}\text { Lactic } \\
\text { acid } \\
\text { produced }\end{array}$ & $\begin{array}{c}\text { Glycine } \\
\text { produced }\end{array}$ \\
\hline No addition & 0.596 & 6.2 & 11.22 & 10.00 & - & - \\
$1.0 \mathrm{mg} / \mathrm{m} l \times 3$ & 0.578 & 7.6 & 2.97 & 2.70 & +++ & + \\
$2.0 \mathrm{mg} / \mathrm{m} l \times 3$ & 0.590 & 7.5 & 3.14 & 2.60 & +++ & + \\
\hline
\end{tabular}

Fermentation medium: glucose $10 \%,\left(\mathrm{NH}_{4}\right)_{2} \mathrm{SO}_{4} 2 \%, \mathrm{CaCO}_{3} 2.4 \%, \mathrm{~K}_{2} \mathrm{HPO}_{4} 0.1 \%$, $\mathrm{MgSO}_{4} \cdot 7 \mathrm{aq} 0.03 \%$, biotin $7.7 \mathrm{r} / 1$ and L-threonine $400 \mu \mathrm{g} / \mathrm{ml}$. Fermentation was run at $28^{\circ}$ for 91 hours.

L-Threonine was added in the medium intermittently every 24 hours after inoculation.

Bacterial growth was measured at the 31st hour and the other data were obtained at the 91st hour after inoculation.

(c) Effect of various amino acids on the production of homoserine and lysine

As described in the preceding section, the inhibitory effect of L-threonine on the homoserine and lysine production has now become clear. In amino acid metablolism, some antagonism between different amino acids $(16,17,18)$ and feed-back mechanisms $(19,20)$ have already been known. Therefore, effects of many amino acids other than threonine on this fermentation were also examined.

These amino acids were added to the starting medium individually and on the 5th day culture broths were analyzed for $\mathrm{pH}$, bacterial growth, and for the production of both homoserine and lysine. The results obtained are shown in Table 3.

None of the amino acids used increased homoserine production. On the contrary, some of them were rather inhibitory on homoserine production. It is interesting to note that such inhibitory amino acids have usually been closely related to homoserine metabolism. They are methionine, cystine, homocysteine and so forth.

Among them, methionine caused the severest suppression of $\mathrm{L}$-homoserine production. Addition of $200 \mu \mathrm{g} / \mathrm{ml}$ of DL-methionine decreased homoserine production to less than one-third of that of control culture. On the other hand, lysine production was increased to about 1.5 times that of control culture.

\section{(d) Suppression of homoserine production by DL-methionine}

In order to get more reliable evidence on the effect of methionine in this fermentation, further experiments with various concentrations of DLmethionine in the starting medium were carried out. Those results are shown in Table 4. 
Table 3. Effect of Amino Acids on L-Homoserine Production.

\begin{tabular}{|c|c|c|c|c|}
\hline $\begin{array}{c}\text { Amino Acid } \\
\text { Added }\end{array}$ & $\mathrm{pH}$ & $\begin{array}{l}\text { Growth } \\
\text { (O.D.) }\end{array}$ & $\begin{array}{c}\text { L-Homoserine } \\
\text { produced } \\
(\mathrm{mg} / \mathrm{ml})\end{array}$ & $\begin{array}{l}\text { L-Lysine } \\
\text { produced } \\
(\mathrm{mg} / \mathrm{ml})\end{array}$ \\
\hline No addition & 7.7 & $0.607(+++)$ & 14.65 & 12.00 \\
\hline $\mathrm{D}$, L-Alanine & 8.4 & ++ \pm & 13.95 & 10.60 \\
\hline L-Arginine- $\mathrm{HCl}$ & 8.4 & +++ & 13.03 & 14.00 \\
\hline L-Glutamate $(\mathrm{Na})$ & 8.3 & +++ & 12.95 & 12.90 \\
\hline Glycine & 8.1 & +++ & 14.45 & 15.60 \\
\hline $\mathrm{L}$-Histidine $\cdot \mathrm{HCl}$ & 8.4 & +++ & 15.83 & 11.40 \\
\hline D, L-Isoleucine & 8.4 & +++ & 12.00 & 8.60 \\
\hline L-Leucine & 8.4 & +++ & 11.33 & 10.00 \\
\hline L-Lysine $\cdot \mathrm{HCl}$ & 8.4 & +++ & 14.28 & 15.40 \\
\hline D, L-Methionine & 5.8 & +++ & 4.00 & 17.70 \\
\hline D, L-Phenylalanine & 7.7 & ++ & 15.03 & 10.90 \\
\hline L-Proline & 8.2 & +++ & 12.40 & 13.00 \\
\hline D, L-Serine & 8.1 & $++t$ & 11.48 & 12.00 \\
\hline D, L-Tryptophan & 8.4 & +++ & 12.10 & 9.80 \\
\hline L-Tyrosine & 8.3 & +++ & 11.93 & 7.60 \\
\hline L-Valine & 8.3 & ++ & 13.13 & 8.50 \\
\hline L-Aspartate (Na) & 8.3 & +++ & 9.45 & 9.20 \\
\hline L-Cystine & 5.8 & 0.680 & 9.93 & 9.70 \\
\hline D, L-Homocysteine & 5.9 & 0.601 & 7.28 & 10.10 \\
\hline $\mathrm{D}$, L-Homoserine & 8.4 & +++ & 10.63 & 11.20 \\
\hline $\mathrm{D}, \mathrm{L}-\alpha$-aminobutylic acid & 7.4 & +++ & 9.70 & 6.80 \\
\hline
\end{tabular}

Fermentation medium: glucose $10 \%,\left(\mathrm{NH}_{4}\right)_{2} \mathrm{SO}_{4} 2 \%, \mathrm{CaCO}_{3} 2 \%$, L-threonine 400 $\mu \mathrm{g} / \mathrm{ml}$, biotin $6.5 \mu \mathrm{g} / l, \mathrm{~K}_{2} \mathrm{HPO}_{4} 0.1 \%$ and $\mathrm{MgSO}_{4} \cdot 7 \mathrm{aq} 0.03 \%$; Each amino acid was added in the medium in an amount of $200 \mu \mathrm{g} / \mathrm{ml}$.

Fermentation was run at $28^{\circ}$ for 5 days.

Homoserine production was markedly decreased by the addition of $200 \mu \mathrm{g} / \mathrm{ml}$ or more of DL-methionine in the starting medium. On the contrary, lysine production was increased by addition of methionine. Interestingly enough the total amounts of both homoserine and lysine produced were rather constant (about $20 \mathrm{mg} / \mathrm{ml}$ ) at every level of methionine concentration. From this, it is presumed that suppression of homoserine production by methionine has forced intermediary metabolism to move forward to lysine production.

\section{(II) Experiments with Intact Cell Suspension}

From the growing culture experiments described above, it has become evident that threonine and methionine have inhibitory effects on homoserine production. In order to observe the mode of those inhibitory effects in 
Table 4. Inhibition of L-Homoserine Production by $\mathrm{D}$, L-Methionine.

\begin{tabular}{|c|c|c|c|c|c|c|c|}
\hline \multirow{2}{*}{$\begin{array}{l}\text { Concentration } \\
\text { of } \\
\mathrm{D}, \mathrm{L}-\mathrm{methionine} \\
\mu \mathrm{g} / \mathrm{m} l\end{array}$} & \multirow{2}{*}{$\begin{array}{l}\text { Growth } \\
\text { (O.D.) } \\
\text { at 3rd day }\end{array}$} & \multicolumn{3}{|c|}{4 th day } & \multicolumn{3}{|c|}{ 5th day } \\
\hline & & $\mathrm{pH}$ & $\begin{array}{l}\text { Homo- } \\
\text { serine } \\
\mathrm{mg} / \mathrm{ml} l\end{array}$ & $\begin{array}{l}\text { Lysine } \\
\mathrm{mg} / \mathrm{ml}\end{array}$ & $\mathrm{pH}$ & $\begin{array}{l}\text { Homo- } \\
\text { serine } \\
\mathrm{mg} / \mathrm{ml}\end{array}$ & $\begin{array}{l}\text { Lysine } \\
\mathrm{mg} / \mathrm{ml}\end{array}$ \\
\hline 0 & 0.890 & 5.6 & 13.08 & 7.89 & 7.1 & 14.38 & 9.58 \\
\hline 50 & 0.910 & 5.6 & 12.38 & 9.48 & 7.1 & 13.25 & 9.53 \\
\hline 100 & 0.845 & 5.8 & 10.58 & 9.83 & 6.8 & 11.33 & 15.25 \\
\hline 200 & 0.845 & 5.8 & 4.35 & 13.10 & 6.0 & 5.75 & 16.15 \\
\hline 300 & 0.765 & 6.1 & 3.23 & 13.70 & 7.2 & 3.40 & 17.55 \\
\hline 400 & 0.770 & 7.2 & 4.70 & 11.65 & 7.3 & 3.90 & 14.22 \\
\hline 600 & 0.825 & 7.1 & 4.90 & 14.65 & 8.1 & 3.50 & 14.90 \\
\hline 800 & 0.815 & 7.1 & 5.18 & 15.15 & 8.3 & 4.80 & 14.75 \\
\hline 1,200 & 0.805 & 7.2 & 6.75 & 14.75 & 8.3 & 5.70 & 14.45 \\
\hline
\end{tabular}

Fermentation medium: glucose $10 \%,\left(\mathrm{NH}_{4}\right)_{2} \mathrm{SO}_{4} 2 \%, \mathrm{CaCO}_{3} 2 \%$, L-threonine $400 \mu \mathrm{g} /$ Fermentation was run at $28^{\circ}$.

$m l$, biotin $7.5 \mu \mathrm{g} / l, \mathrm{~K}_{2} \mathrm{HPO}_{4} 0.1 \%$ and $\mathrm{MgSO}_{4} \cdot 7 \mathrm{aq} 0.03 \%$.

broader light, experiments with intact cell suspensions were carried out.

(a) Effect of methionine on the formation of enzyme system for homoserine and lysine biosynthesis

M. glutamicus 534-Co147. strain was grown on three different media, i. e., (1) synthetic medium, (2) synthetic medium containing DL-methionine and (3) natural medium. The compositions of these media are shown in Table 5. Bacterial cells were harvested from each culture broth and intact cell suspensions were prepared as described in the part on experimental methods. The results obtained from the experiments with these intact cell suspensions are shown in Table 5 .

As shown in Table 5, homoserine productivity was predominant over lysine productivity in the cells obtained from the synthetic medium. On the other hand, cells from the methionine-containing synthetic medium showed much decreased homoserine productivity and much increased lysine productivity. Cells from the natural medium also showed decreased homoserine productivity but the lysine productivity was not so different as that of cells obtained from synthetic medium.

These results were quite coincident with those of growing culture experiments (see Table 4), and this supported the presumption that methionine might repress formation of some enzyme system for homoserine biosynthesis.

(b) Effect of DL-methionine on the enzyme activity for homoserine and lysine biosynthesis

In the preceding section, the effects of DL-methionine on the formation of enzyme systems for homoserine and lysine biosynthesis were examined. Further investigations on the effect of DL-methionine on the enzyme activity 
Table 5. Homoserine and Lysine Synthesizing Abilities of Intact Cells Obtained from Different Media.

\begin{tabular}{l|c|c}
\hline Cells Harvested & $\begin{array}{c}\text { L-Homoserine } \\
\text { synthesized }\end{array}$ & $\begin{array}{c}\text { L-Lysine } \\
\text { synthesized }\end{array}$ \\
\hline $\begin{array}{l}\text { From synthetic medium } \\
\text { From synthetic medium } \\
\text { + D, L-methionine }\end{array}$ & $18.7 \mu \mathrm{M}$ & $12.5 \mu \mathrm{M}$ \\
From natural medium & $10.1 \mu \mathrm{M}$ & $23.4 \mu \mathrm{M}$ \\
& $12.1 \mu \mathrm{M}$ & $12.8 \mu \mathrm{M}$ \\
\hline
\end{tabular}

Synthetic medium: glucose $10 \%,\left(\mathrm{NH}_{4}\right)_{2} \mathrm{SO}_{4} 2 \%, \mathrm{CaCO}_{3} 2 \%$, L-threonine $400 \mu \mathrm{g} / \mathrm{m}$, biotin $6.5 \mu \mathrm{g} / l, \mathrm{~K}_{2} \mathrm{HPO}_{4} 0.1 \%$, and $\mathrm{MgSO}_{4} \cdot 7 \mathrm{aq} 0.03 \%$.

Synthetic medium $+\mathrm{D}$, L-methionine: $400 \mu \mathrm{g} / \mathrm{ml}$ of $\mathrm{D}$, L-methionine was added to the above medium.

Natural medium: glucose $10 \%,\left(\mathrm{NH}_{4}\right)_{2} \mathrm{SO}_{4} 2 \%, \mathrm{CaCO}_{3} 2 \%, \mathrm{NZ}$ amine $1.0 \%$, yeast extract $0.5 \%, \mathrm{~K}_{2} \mathrm{HPO}_{4} 0.1 \%$, and $\mathrm{MgSO}_{4} \cdot 7 \mathrm{aq} 0.03 \%$.

Composition of Reaction Mixture: Potassium phosphate buffer ( $\mathrm{pH} 7.3$ ) $350 \mu \mathrm{M}$, $\mathrm{MgSO}_{4} \cdot 7 \mathrm{aq} 10 \mu \mathrm{M}$, glucose $100 \mu \mathrm{M},\left(\mathrm{NH}_{4}\right)_{2} \mathrm{SO}_{4} 200 \mu \mathrm{M}$, and intact cells $100 \mathrm{mg}$ (dry wt.) in $5 \mathrm{ml}$ of total volume.

Reaction mixture was incubated at $30^{\circ}$ for 6 hours on a shaking device.

for homoserine and lysine biosynthesis were carried out. Cells from synthetic medium and methionine-containing medium (see Table 5) were also used. Different amounts of DL-methionine as indicated in Table 6 were added in the reaction mixtures, and the amounts of homoserine and lysine synthesized were assayed. The results are shown in Table 6 .

Neither enzyme activity for homoserine nor lysine biosynthesis was inhibited by DL-methionine.

Table 6. Effect of D, L-Methionine on Homoserine and Lysine Syntheses by Intact Cells.

\begin{tabular}{|c|c|c|c|}
\hline Cells Harvested & $\begin{array}{l}\text { Concn. of } \\
\mathrm{D}, \text { L-methionine } \\
\text { in reaction } \\
\text { mixture }^{* *}\end{array}$ & $\begin{array}{l}\text { Homoserine } \\
\text { synthesized }\end{array}$ & $\begin{array}{c}\text { Lysine } \\
\text { synthesized }\end{array}$ \\
\hline From Synthetic medium* & $\begin{array}{l}\text { None } \\
10^{-4} \mathrm{M} \\
10^{-3} \quad " \prime \\
10^{-2} \quad "\end{array}$ & $\begin{array}{l}18.5 \mu \mathrm{M} \\
22.4 " \\
20.8 " \\
22.0 "\end{array}$ & $\begin{array}{l}12.5 \mu \mathrm{M} \\
13.1 " \prime \\
15.5 " \\
19.4 "\end{array}$ \\
\hline $\begin{array}{l}\text { From Synthetic medium } \\
\quad+D, \text { L-methionine }{ }^{*}\end{array}$ & $\begin{array}{l}\text { None } \\
10^{-4} \mathrm{M} \\
10^{-3} \quad / \\
10^{-2} \quad " \prime\end{array}$ & $\begin{array}{r}10.1 " ~ \\
9.4 " \\
10.5 " \\
11.6 "\end{array}$ & $\begin{array}{l}23.4 " \prime \\
20.9 " \\
21.4 " \\
30.5 "\end{array}$ \\
\hline
\end{tabular}

* Compositions of fermentation media used were the same as indicated in Table 5.

** Compositions of reaction mixtures were the same as indicated in Table 5. D, Lmethionine was added in the reaction mixture in an amount as described above. Reaction mixture was incubated at $30^{\circ}$ for 6 hours on a shaking device. 
Summarizing the results presented in Tables 5 and 6 , it can be said that DL-methionine represses the formation of certain enzyme system for homoserine biosynthesis but does not inhibit the enzyme activity for the same.

(c) Effect of L-threonine on the enzyme activity for homoserine and ly. sine biosynthesis

NAKaYAma et al. (20) reported that both threonine and homoserine strongly inhibited the enzyme activity for lysine production in the lysine fermentation with a homoserine requirring mutant of $M$. glutamicus. As were shown in Figure 1 and Table 2, excess amount of threonine strongly inhibited the production of homoserine. Therefore, the effect of L-threonine on the enzyme activity for homoserine and lysine production was investigated with intact cells from both synthetic and methionine-containing media. In Table 7, the experimental results are shown.

Table 7. Effect of L-Threonine on Homoserine and Lysine Synthesis by Intact Cells.

\begin{tabular}{|c|c|c|c|}
\hline Cells harvested & $\begin{array}{l}\text { Concn. of } \\
\mathrm{D}, \mathrm{L}-\mathrm{methionine} \\
\text { in reaction } \\
\text { mixture }\end{array}$ & $\begin{array}{l}\text { Homoserine } \\
\text { synthesized }\end{array}$ & $\begin{array}{c}\text { Lysine } \\
\text { synthesized }\end{array}$ \\
\hline From synthetic medium* & $\begin{array}{c}\text { None } \\
10^{-4} \mathrm{M} \\
5 \times 10^{-4} \mathrm{M} \\
10^{-3} \mathrm{M} \\
5 \times 10^{-3} \mathrm{M}\end{array}$ & $\begin{array}{c}18.7 \mu \mathrm{M} \\
20.8 " \\
3.8 " \\
4.6 " \\
8.8 "\end{array}$ & $\begin{array}{r}12.5 \mu \mathrm{M} \\
8.5 " ~ \\
1.7 " \\
0.1 " \\
0.0 "\end{array}$ \\
\hline $\begin{array}{l}\text { From synthetic medium } \\
\quad+D, \text { L-methionine }\end{array}$ & $\begin{array}{c}\text { None } \\
10^{-4} \mathrm{M} \\
5 \times 10^{-4} \mathrm{M} \\
10^{-3} \mathrm{M} \\
5 \times 10^{-3} \mathrm{M}\end{array}$ & $\begin{array}{r}10.1 " ~ \\
8.4 " \\
7.4 " \\
5.8 " \\
4.8 "\end{array}$ & $\begin{array}{r}23.4 " ~ \\
29.1 " \\
14.5 " \\
3.8 " \\
0.0 "\end{array}$ \\
\hline
\end{tabular}

* Compositions of fermentation media used were the same as indicated in Table 5 .

* Composition of reaction mixture was the same as indicated in Table 5 . LThreonine was added to the reaction mixture in an amount as described above. Reaction mixture was incubated at $30^{\circ}$ for 6 hours on a shaking device.

From Table 7 , it can be seen that the addition of more than $5 \times$ $10^{-4} \mathrm{M}$ of $\mathrm{L}$-threonine in the reaction mixture has caused a severe decrease in both homoserine and lysine productions. From this, it is evident that Lthreonine strongly inhibited the enzyme activities for both homoserine and lysine biosyntheses.

\section{DISCUSSION}

Based on the experimental results described above, the metabolic pathway for homoserine biosynthesis and the possible sites of "negative feed-back control" mechanisms caused by threonine and methionine are schematically shown in Figure 3. 


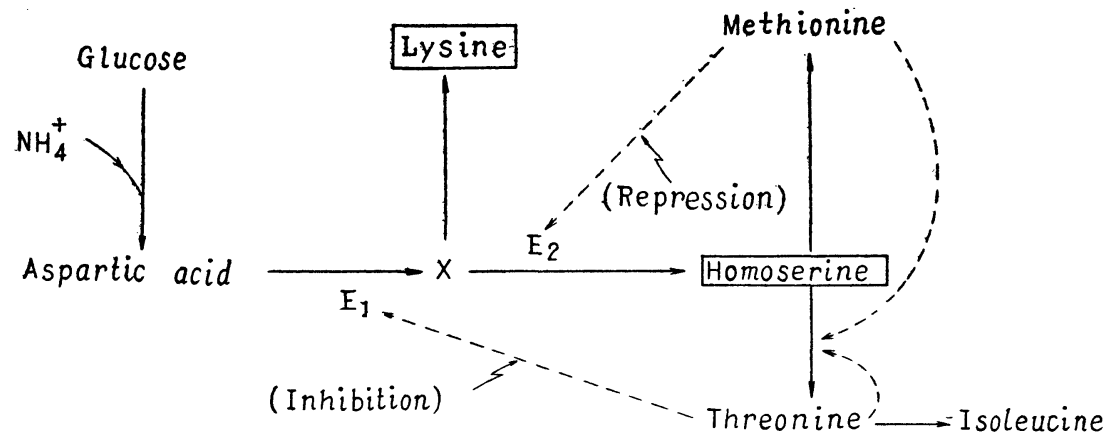

Fig. 3. Schematic Diagram for the Biosynthesis of Homoserine and Lysine, and Possible Sites of "Negative Feed-Back Control" Mechanisms Caused by Threonine and Methionine.

$\longrightarrow$ Biosynthetic Path. $\quad-\rightarrow$ Inhibition (or Repression)

(a) M. glutamicus $534-$ Co147 strain is a threonine requiring mutant and can accumulate a large quantity of L-homoserine in the culture broths if it is cultivated in appropriate media. From this evidence, it can easily be presumed that a certain enzyme system between homoserine and threonine might be blocked. According to the reports by Davis (25), and BLACK and Wright (26), it was suggested that both homoserine and lysine were synthesized from aspartic acid via a common intermediate $\mathrm{X}$ (see Figure 3). In the fermentation with $M$. glutamicus $534-$ Co147 strain, both homoserine and lysine were extracellularly accumulated in large amounts. This may give an additional support to the correctness of the assumption mentioned above.

(b) The present authors wish to discuss on the two " negative feed-back control" mechanisms caused by threonine and methionine in this fermentation. As previously described by PARDEE (27), there are two types of "negative feed-back control" mechanisms. One is "repression" which is suppression of enzyme formation, and the other is "inhibition" which is suppression of enzyme activity.

In the present fermentation, methionine suppressed the formation of certain enzyme system for homoserine biosynthesis (see Table 5). So, it is " repression." And also, in this case, the decrease of homoserine production was always accompanied by an increase of lysine production. Therefore, the " repression" by an methionine might occur on certain enzymes at a stage between an intermediate " $\mathrm{X}$ " and homoserine. If the enzyme system is designated as " $\mathrm{E}_{2}$," $\mathrm{E}_{2}$ must be repressed by methionine. Repression of $\mathrm{E}_{2}$ by methionine may decrease the conversion of $\mathrm{X}$ to homoserine and, as the result, the intermediate $\mathrm{X}$ may be forced to move forward to lysine production. This assumption can reasonably explain the experimental results.

On the other hand, threonine suppressed the enzyme activities for both homoserine and lysine biosyntheses. So, it is " inhibition." Simultaneous inhibition of the production of both amino acids suggested that this inhibition 
might occur on a certain enzyme or enzymes prior to the $\mathrm{X}$ formation. If the enzyme system is designated as " $E_{1}$ ", $E_{1}$ must be inhibited by threonine (see Figure 3).

MAGASANIK (27) has commented on the "negative feed-back control" mechanism as follows: "In general, only the first enzyme of a particular biosynthetic sequence seems to be subject to inhibition by the ultimate product, while many of the enzymes of the sequence may be subjected to repression." According to his comment, the assuinption presented in Figure 3 must be considered reasonable.

(c) Concerning the pathway for threonine biosynthesis from homoserine, Wormser and PARDEE (28) reported the inhibition of homoserinekinase by threonine, and FuJII et al. (29) reported that methionine inhibited the conversion of homoserine to threonine in growing culture experiments. Together with the two "negative feed-back control" mechanisms found by the present authors, therefore, at least four types of inhibition or repression lie on the biosynthetic pathway of threonine from glucose. This can account for the fact that threonine was scarcely found in culture broths when the microorganisms were cultivated in conventional media.

(d) In the recent advance in fermentative production of amino acids, auxotrophic mutants of $M$. glutamicus have played significant roles, for example, biotin-less strains in glutamic acid fermentation (21), homoserine-less strains in lysine fermentation (20), arginine-less strains in ornithine fermentation (30) and so forth. In order to achieve good yields of products in those fermentations, appropriate amounts of required substances were always necessary. However, it is common throughout these fermentations that an excess amount of substances required was always injurious to the production of amino acid wanted, though it stimulated bacterial growth more strongly. Such phenomena have also been found in the homoserine fermentation with $M$. glutamicus 534-Co147 strain. The strain requires threonine for the homoserine production as well as for its growth. However, an excess amount of threonine caused a sharp decrease of homoserine production, while bacterial growth was rather stimulated.

These facts may have important meaning not only in the amino acid fermentations using auxotrophic mutants but also in many other fermentative productions with auxotrophs.

\section{SUMMARY}

Fermentative production of L-homoserine was achieved by using a threonine requiring mutant of Micrococcus glutamicus. This strain produced a large quantity of L-homoserine as well as L-lysine in the culture broths if it was cultivated under appropriate conditions.

During the studies on fermentative production of L-homoserine, it was found that $\mathrm{L}$-threonine concentration affected the formation of $\mathrm{L}$-homoserine and L-lysine to a great extent. Maximum productions of L-homoserine and 
L-lysine were attained when L-threonine concentrations were $400 \mu \mathrm{g} / \mathrm{ml}$ and 300 $\mu \mathrm{g} / \mathrm{ml}$, respectively. And an excess amount of threonine caused a sharp decrease in both amino acid productions. The effects of various amino acids on this fermentation were also examined. As the results, two "negative feed-back control" phenomena caused by threonine and methionine were observed.

Further investigations using intact cell suspension revealed the mode of action of the two amino acids in the "negative feed-back" mechanisms. Experimental results showed that threonine inhibited a certain enzyme activity involved in the biosynthetic path of homoserine, and methionine repressed the formation of a certain enzyme on the same path.

Based on these experimental results the sites of these "negative feedback" mechanisms were discussed.

\section{REFERENCES}

(1) H. J. Test, N. H. Horowitz, and M. Fling: J. Biol. Chem., 172, 651 (1948).

(2) M. Fling, and N. H. Horowitz: J. Biol. Chem., 190, 277 (1951).

( 3 ) P. H. Abelson, E. Bolton, R. Britten, D. B. Cowie, and R. B. Roberts: Proc. Natl. Acad. Sci, U.S.A., 39, 1020 (1953).

(4) P. H. Abelson: J. Biol. Chem., 206, 335 (1954).

(5) S. Kinoshita, K. Nakayama, and S. Kitada: Bull. Agr. Chem. Soc. Japan, 22, 176 (1958).

(6) S. Kinoshita, H. Samejima, K. Nakayama, T. Nara, and C. Fujita: J. Gen. Appl. Microbiol. (Japan), 6, 193 (1960).

(7) H. Samejima, T. Nara, C. Fujita, and S. Kinoshita: J. Agr. Chem. Soc. Japan, 34, 750 (1960).

(8) H. Samejima, T. Nara, C. Fujita, and S. Kinoshita: J. Agr. Chem. Soc. Japan, 34, 754 (1960).

(9) H. Samejima, T. Nara, C. Fujita, and S. Kinoshita: J. Agr. Chem. Soc. Japan, 34, 824 (1960).

(10) H. Samejima, T. Nara, C. Fujita, and S. Kinoshita: J. Agr. Chem. Soc. Japan, 34, 828 (1960).

(11) K. Nakayama, S. Kitada, Z. Sato, and S. Kinoshita: J. Gen. Appl. Microbiol., 7, 41 (1961).

(12) G. N. Cohen, and M. L. Hirsch: J. Bacteriol., 67, 182 (1954).

(13) J. A. Nelson: Federation Proc., 5, 148 (1946).

(14) M. Somogyi: J. Biol. Chem., 160, 61 (1945).

(15) K. Tanaka, T. Iwasaki, and S. Kinosh'TA: J. Agr. Chem. Soc. Japan, 34, 593 (1960).

(16) E. L. TAtum: Cold Spring Harbor Symposia Quant. Biol., 11, 278 (1946).

(17) D. Rowley: J. Gen. Microbiol., 9, 37 (1953).

(18) J. O. Lampen, and M. J. Jones: Arch. Biochem. Biophys., 13, 47 (1947).

(19) S. Udaka, and S. Kinoshita: J. Gen. Appl. Mucrobiol. (Japan), 4, 283 (1958).

(20) K. Nakayama, S. Kitada, and S. Kinoshita: Symposium on Amino Acid Fermentation, 2, 105 (1960).

(21) K. Tanaka, S. Akita, K. Kimura, and S. Kinoshita: J. Agr. Chem. Soc. Japan, 34, 600 (1960). 
(22) K. Nakayama, S. Kitada, and S. Kinoshita: Symposium on Amino Acid Fermentation, 2, 77 (1960).

(23) D. A. Miller, and S. Simmonds: Proc. Natl. Acad. Sci., U.S.A., 43, 195 (1957).

(24) G. Y. Vilenkina: Doklady Akad. Nauk., S.S.S.R., 84, 559 (1952).

(25) B. D. DAvis: Nature, 169, 534 (1952).

(26) S. BlaCK and N. G. Wrighr: J. Biol. Chem., 213, 27 (1955).

(27) A. R. PARDEE, in "Regulation of Cell Metabolism", CIBA Foundation Symposia, Wolstenholme, G.E.W., and O'Connor, C.M., ed., J. \& A. Churchill Ltd., London. England, 1959, p. 307.

(28) E. H. Wormser, and A. R. Pardee: Arch. Biochem. Biophys., 78, 416 (1958).

(29) Y. FujII, J. Shibuya, H. Ujile, M. Kojima, H. Togawa, and T. Uemura: Symposium on Amino Acid Fermentation, 1, 75 (1959).

(30) S. Udaka, and S. Kinoshita: J. Gen. Appl. Microbiol., 4, 272 (1958). 